\title{
OPTIMASI METODE PURIFIKASI EKSTRAK DAUN SIRIH HIJAU (Piper betle Linn) YANG MEMILIKI AKTIVITAS ANTIBAKTERI TERHADAP BAKTERI Propionibacterium Acnes
}

\author{
W. A. Wijaya, N. L. P. V. Paramita*, dan N. M. P. Susanti \\ Program Studi Farmasi Fakultas Matematika dan Ilmu Pengetahuan Alam Universitas Udayana \\ *E-mail: vidya_paramita@unud.ac.id
}

\begin{abstract}
ABSTRAK
Propionibacterium acnes merupakan bakteri utama penyebab jerawat, dimana dilaporkan dalam suatu penelitian bahwa persentase ditemukannya bakteri $P$. acnes pada lesi jerawat sebesar 78,8\%. Daun sirih hijau telah banyak dilaporkan memiliki aktivitas sebagai antibakteri. Kemampuan antibakteri daun sirih hijau disebabkan karena adanya senyawa golongan fenol yang terdiri dari kavikol, hydroxychavicol, chavibetol, estragol, eugenol, carvacrol dan golongan senyawa seskuiterpen. Penelitian ini bertujuan untuk mengetahui metode optimum yang menghasilkan aktivitas antibakteri terhadap bakteri $P$. acnes dari enam fraksi yang diperoleh. Metode purifikasi yang digunakan untuk mendapatkan ke-6 fraksi tersebut adalah LLE dengan penggunaan pelarut polar etanol-air yang tidak bercampur dengan pelarut heksan, kloroform dan dietileter. Ke-6 fraksi uji tersebut selanjutnya diuji aktivitas antibakterinya dengan metode difusi disk dan dilanjutkan dengan metode tambahan yaitu KLT bioautografi kontak. Analisis data yang dilakukan secara deskriptif terhadap nilai diameter zona hambat dengan mengkategorikannya berdasarkan CLSI dan terhadap hasil skrining fitokimia. Dari hasil penelitian ini diperoleh hanya dua fraksi yaitu fraksi n-heksan dan fraksi dietileter yang mampu menghambat pertumbuhan bakteri $P$. acnes dengan nilai diameter zona hambat sebesar $8 \mathrm{~mm}$ dan $9 \mathrm{~mm}$. Metode purifikasi ekstrak daun sirih hijau yang merupakan gabungan metode maserasi dan LLE yang dilakukan belum optimal karena dilihat dari 6 fraksi yaitu fraksi etanol-air (FEA I), etanolair (FEA II), etanol-air (FEA III), kloroform, dietil eter dan fraksi n- belum mampu menghambat pertumbuhan bakteri $P$. acnes dimana ke-6 fraksi tersebut termasuk dalam kategori resistant.
\end{abstract}

Kata Kunci: difusi disk, optimasi metode, Propionibacterium acnes, sirih hijau

\begin{abstract}
Propionibacterium acnes is the main bacteria causing acne, which was reported in a study that the percentage of $P$. acnes bacteria found in acne lesions was $78.8 \%$. Green betel leaf has been reported to have antibacterial activity. The antibacterial potency of green betel leaves is due to the presence of phenol group compounds consisting of kavikol, hydroxychavicol, chavibetol, estragol, eugenol, carvacrol and the group of sesquiterpen compound. The aim of this research was to find out the optimum method producing an antibacterial activity against $P$. acnes bacteria from six fractions obtained. The purification method used to obtain the six fractions was LLE using of water- ethanol which is soluble in hexane, chloroform and diethylether. The six fractions of the test were then examined for antibacterial activity with the application of the disk diffusion method followed by additional method of contact TLC bioautography. The data analysis was done descriptively to the value of the inhibition zone diameter by categorizing it based on CLSI and the results of the phytochemical scores. In this study, it was obtained only two fractions, namely the fraction of n-hexane and diethylether fraction that were capable of inhibiting the growth of P. acnes bacteria with the value of inhibition zone diameter of $8 \mathrm{~mm}$ and $9 \mathrm{~mm}$. The purification method of the green betel leaves extract which was the combination of maseration and LLE method is not optimal yet as can be seen from the 6 fractions, namely the fractions of ethanol-water (FEA I), ethanol-water (FEA II), ethanol-water (FEA III) chloroform fraction, diethyl ether fraction and n-hexane fraction were not able to inhibit the growth of $P$. acnes bacteria where this six factions are included in the resistant category.
\end{abstract}

Keywords: disk diffusion optimization methods, Piper betle, Propionibacterium acnes. 


\section{PENDAHULUAN}

Propionibacterium acnes merupakan bakteri utama penyebab jerawat, dimana dilaporkan dalam suatu penelitian bahwa persentase ditemukannya bakteri $P$. acnes pada lesi jerawat sebesar $78,8 \%$ (Sylvia, 2010). Daun sirih hijau telah banyak dilaporkan memiliki aktivitas sebagai antibakteri.

Berdasarkan penelitian Putri (2010), ekstrak etanol daun sirih hijau memiliki aktivitas antibakteri terhadap bakteri $P$. acnes dengan nilai Kadar Hambat Minimum (KHM) sebesar 0,25\%. Menurut Kursia et al., (2016) bahwa pada konsentrasi 5\% ekstrak etilasetat daun sirih hijau menghasilkan daya hambat $15 \mathrm{~mm}$ terhadap bakteri Staphylococcus Epidermidis yang merupakan salah satu bakteri penyebab jerawat. Salah satu komponen penting dalam daun sirih hijau adalah minyak atsiri. Kemampuan antibakteri daun sirih hijau disebabkan karena adanya senyawa golongan fenol yang terdiri dari kavikol, hydroxylchavicol, chavibetol, estragol, eugenol, carvacrol dan golongan senyawa seskuiterpen.

Hasil uji bioautografi ekstrak terpurifikasi daun sirih hijau diperoleh satu spot dengan nilai Rf 3.7 dimana dari nilai Rf 3.7 itu diketahui senyawa aktif yang berperan sebagai antibakteri terhadap $P$. acnes yaitu golongan senyawa fenol dan terpenoid (Paramita et al., 2016)

Berdasarkan penelitian Jesonbabu et al., (2011), dikatakan bahwa hydroxychavicol berperan sebagai antibakteri. Hydroxychavicol mampu menghambat pertumbuhan bakteri dengan MIC $200 \mu \mathrm{g} / \mathrm{mL}$ untuk Staphylococcus aureus dan Staphylococcus pyogenes dan $400 \mu \mathrm{g} / \mathrm{ml}$ untuk $E$. coli, Salmonella typhi dan Shigella dysentriea (Jesonbabu et al., 2011).

Metode yang digunakan untuk mem-peroleh ekstrak terpurifikasi sirih hijau adalah gabungan metode maserasi dan Liquid-liquid extraction. Proses maserasi dilakukan dengan menggunakan pelarut etanol 96\% hingga diperoleh ekstrak kasar dan dilakukan partisi menggunakan dua macam pelarut yaitu n-heksan dan akuades (1:2) v/v sehingga diperoleh fraksi heksan dan fraksi etanolair. Fraksi etanol-air yang dihasilkan termasuk dalam katagori intermediate (Budiningrum, 2016).

Pada penelitian ini dilakukan optimasi metode fraksinasi dengan maserasi serbuk daun sirih hijau menggunakan etanol 96\% dan LLE dengan n-heksan: air (1:1) v/v hingga diperoleh fraksi n-heksan dan fraksi etanol air. Fraksi etanol air selanjutnya di LLE dengan masing masing pelarut kloroform dan dietileter. Fraksi n-heksan (FH), fraksi etanol-air (FEA I), fraksi etanol-air (FEA II), fraksi etanol-air (FEA III), fraksi klorofrom (FK) dan fraksi dietileter (FD) diuji aktivitas antibakteri untuk mengetahui metode optimumnya. Metode optimum adalah metode yang menghasilkan aktivitas antibakteri suspectible.

\section{Bahan}

\section{MATERI DAN METODE}

Bahan-bahan kimia yang digunakan dalam penelitian ini yaitu serbuk daun sirih hijau (Piper betle L.), etanol 96\% (teknis, Brataco), aquadest, n-heksan (teknis, Brataco), kloroform p.a (Brataco) dan dietileter p.a (Brataco),media Mueller Hinton Broth (MHB) (Oxoid $\AA), \quad$ Agar (Conda), Doksisiklin disk (Oxoid®), bakteri P. acnes, etanol p.a (Brataco), standar Mc. Farland.

\section{Peralatan}

Alat yang digunakan dalam penelitian ini yaitu vaccum rotary evaporator (Eyela $\AA$ ), corong pisah (Iwaki-Pyrex®), timbangan elektrik (ADAM AFP-360), laminar air flow cabinet (Telstar), cawan petri (Citotest), lemari pendingin (Uchida), inkubator (Memmert), (sprider) lampu UV (CAMAG).

\section{Cara Kerja \\ Determinasi Tanaman}

Determinasi dan identifikasi tanaman bertujuan untuk menetapkan kebenaran sampel daun sirih hijau (Piper betle L.) yang digunakan dalam penelitian. Hal ini berkaitan dengan ciri-ciri morfologis yang ada pada tanaman sirih hijau terhadap kepustakaan dan dibuktikan di Lembaga Ilmu Pengetahuan Indonesia (LIPI), UPT Balai Konservasi Tumbuhan Kebun Raya "Eka Karya" Bali, Bedugul, Provinsi Bali.

\section{Pengambilan dan Preparasi Sampel}

Sampel segar daun sirih hijau (Piper betle L.) dikumpulkan dari Desa Nongan daerah karangasem di Provinsi Bali. Daun yang telah dikumpulkan dicuci dengan air mengalir, dipilih hanya daun yang berwarna hijau, kemudian 
dikeringkan pada suhu kamar dan dihindarkan dari paparan sinar matahari langsung karena dapat menyababkan senyawa aktif yang memiliki aktivitas antibakteri dapat rusak oleh paparan sinar matahari secara langsung. Sampel yang telah kering diserbukkan dengan menggunakan blender. Serbuk disimpan dalam wadah tertutup kedap.

\section{Pembuatan Ekstrak dan Purifikasi Ekstrak Etanol Daun Sirih Hijau (Piper betle $\mathbf{L}$.)}

Pembuatan ekstrak etanol daun sirih hijau (Piper betle L.) dilakukan dengan metode maserasi. Serbuk daun sirih hijau (Piper betle L.) ditimbang sebanyak 50 gram kemudian ditempatkan dalam toples kaca tertutup, kemudian direndam dengan $300 \mathrm{~mL}$ etanol $96 \%$ selama \pm 24 jam pada suhu ruang $32^{\circ} \mathrm{C}$ terlindung dari cahaya dengan pengadukan sesekali. Hasil maserasi disaring, diukur filtrat yang diperoleh. Residu dimaserasi kembali dengan etanol 96\%. Dilakukan dua kali pengulangan. Seluruh filtrat yang diperoleh ditampung menjadi satu dan diuapkan dengan menggunakan alat rotary evaporator pada suhu $40^{\circ} \mathrm{C}$, sehingga diperoleh ekstrak kental. Ekstrak kental etanol daun sirih hijau (Piper betle L.) dilarutkan dengan etanol 96\% kemudian dimasukkan dalam corong pisah $100 \mathrm{ml}$. Ditambahkan pelarut $n$-heksan dan aquadest (1:1) v/v. Kemudian dilakukan penggojogan dan didiamkan hingga terbentuk 2 fase yaitu fase atas yang merupakan fase n-heksan dan fase bawah yaitu fase etanol-air. Kedua fase ditampung terpisah. Selanjutnya fraksi etanol-air (FEA I) dibagi menjadi 2 untuk dilakukan LLE dengan pelarut kloroform dan dietileter, sehingga diperoleh fraksi n-heksan (FH), fraksi etanol-air (FEA I), fraksi etanol-air (FEA II), fraksi etanolair (FEA III), fraksi klorofrom (FK) dan fraksi dietileter (FD). Ke-6 fraksi diuapkan dengan menggunakan rotary evaporator pada suhu $40^{\circ} \mathrm{C}$ sehingga diperoleh fraksi kental daun sirih hijau (Piper betle L.) (Widyaningtiyas, 2014).

Serbuk serbuk daun sirih hijau yang dimulai dari maserasi menggunakan teknik maserasi menggunakan pelarut etanol 96\%. Hasil ekstrak etanol dipisahkan denganmetode LLE pelarut nheksan: air (1:1) v/v hingga diperoleh fraksi nheksan (FH) dan fraksi etanol air (FEA I). Hasil FEA I selanjutnya dibagi menjadi 2 Bagian. Masing - masing bagian di ekstraksi dengan metode LLE menggunakan pelarut kloroform dan dietileter sehingga akan menghasilkan 4 fraksi yaitu fraksi etanol-air (FEA II) dan Fraksi Kloroform (FK) serta fraksi etanol-air (FEA III) dan Fraksi dietil eter (FD).

\section{Penetapan Kadar Air dengan Destilasi Toulena}

Ekstrak kental etanol daun sirih hijau (Piper betle L.) ditimbang seksama 5 gram, dimasukkan ke dalam labu kering. Dimasukkan lebih kurang $200 \mathrm{~mL}$ toluen jenuh air ke dalam labu, pasang rangkaian alat. Dimasukkan toluen jenuh air ke dalam tabung penerima melalui pendingin sampai leher alat penampung. Labu dipanaskan hati-hati selama 15 menit. Setelah toluen mulai mendidih, atur penyulingan dengan kecepatan lebih kurang dari 2 tetes tiap detik, hingga sebagian besar air tersuling, kemudian kecepatan penyulingan dinaikkan hingga 4 tetes tiap detik. Penyulingan dilanjutkan selama 5 menit. Tabung penerima didinginkan sampai suhu ruang. Volume air dibaca setelah air dan toluen memisah sempurna. Percobaan ini diulang sebanyak dua kali. Kadar air dihitung dalam \% v/b (Zainab, 2016; Isnawati, 2013).

\section{Uji Skrining Fitokimia dengan KLT}

Sampel uji yaitu ekstrak etanol daun sirih hijau (Piper betle L.), fraksi n-heksan (FH), fraksi etanol-air (FEA I), fraksi etanol-air (FEA II), fraksi etanol-air (FEA III), fraksi klorofrom (FK) dan fraksi dietileter (FD) ditotolkan sebanyak 5 totolan pada Plat KLT Al Silika Gel $\mathrm{GF}_{254}$ ukuran $8 \times 10 \mathrm{~cm}$. Plat selanjutnya dielusi dengan fase gerak toluen : etil asetat (93: 7) v/v (Wirasuta dan Paramita, 2016). Plat KLT yang telah dielusi selanjutnya dikarakterisasi dengan pereaksi pendeteksi pereaksi Anisaldehid-asam sulfat P, Folin-Ciocalteau dan $\mathrm{FeCl}_{3}$.

\section{Uji Aktivitas Antibakteri}

Suspensi bakteri dipipet sebanyak $50 \mu \mathrm{L}$ kemudian diteteskan pada media Mueller Hinton Agar (MHA). Suspensi bakteri disebar dengan menggunakan hoky stick. Konsenstrasi sampel uji dari FH , FEA I, FEA II, FK, FEA III dan FD yaitu $640 \mathrm{mg} / \mathrm{mL}$. sebanyak $2020 \mu \mathrm{L}$ masing-masing fraksi diimpregnasikan pada kertas cakram berukuran $6 \mathrm{~mm}$. Kontrol positif pengujian adalah doksisiklin disk dengan konsentrasi $30 \mu \mathrm{g} /$ disk. 
Cawan petri yang telah ditempelkan kertas cakram lalu diinkubasi pada suhu $37^{\circ} \mathrm{C}$ selama 24 jam. Pengujian aktivitas antibakteri dilakukan sebanyak 3 kali. Adanya aktivitas antibakteri dari sampel ditunjukkan oleh terbentuknya zona bening disekitar kertas cakram pada media.

\section{Analisis Data}

Data aktivitas daun sirih hijau (Piper betle L.) terhadap bakteri P. acnes berupa diameter zona hambat.. Data penelitian ini dianalisis dengan analisis deskriptif. Analisis data dilakukan secara deskriptif terhadap nilai diameter zona hambat dengan mengkategorikannya berdasarkan Clinical and Laboratory Standards Institute (CLSI) yaitu resistant $\leq 14 \mathrm{~mm}$, intermediate $15-19 \mathrm{~mm}$, susceptible $\geq 20 \mathrm{~mm}$

\section{HASIL DAN PEMBAHASAN}

\section{Determinasi Tanaman}

Hasil determinasi menunjukkan bahwa sampel tanaman yang digunakan dalam penelitian adalah daun sirih hijau (Piper betle L.) dari Famili Piperaceae.

\section{Preparasi sampel}

Sampel daun sirih hijau yang digunakan pada penelitian ini diperoleh dari Desa Nongan. Pada penelitian sebelumnya oleh Widyaningtias (2014) dan Budiningrum (2016) sampel daun sirih hijau yang digunakan diperoleh dari Desa Duda, Karangasem. Perbedaan tempat pengambilan sampel sirih hijau akan berpengaruh terhadap persentase komposisi senyawa kimia dalam tanaman tersebut. Metode pengeringan sampel sirih hijau pada penelitian ini menggunakan cara diangin anginkan di diluar ruangan, dimana selama proses pengeringan tidak terdapat kontrol suhu lingkungan sehingga tidak dapat ditarik kesimpulan apakah terdapat perbedaan senyawa kimia akibat menggunakan metode pengeringan yang berbeda dengan metode penelitian oleh Widyaningtias (2014) dan Budiningrum (2016). Menurut Magdalena dan Kusnadi, (2015) suhu yang tinggi mampu mendegradasi senyawa fenolik yang terdapat pada sirih hijau yang memiliki aktivitas antibakteri.
Penetapan Kadar Air dengan Destilasi Toulena

Berdasarkan hasil kadar air hasil destilasi menggunakan pelarut toluena pada serbuk daun sirih hijau diperoleh persentasi nilai kadar air sebesar 3,33\% yang menunjukan bahwa kadar air dari simplisia sirih hijau telah memenuhi syarat sesuai ketentuan Farmakope Herbal Indonesia yaitu kadar air simplisia tidak lebih dari $10 \%$.

\section{Pembuatan Ekstrak dan Purifikasi Ekstrak Etanol Daun Sirih Hijau (Piper betle L.)}

Pada penelitian ini pembuatan ekstrak dilakukan dengan cara maserasi dengan etanol $96 \%$ selama 1 hari pada suhu ruang yaitu suhu 28$32^{\circ} \mathrm{C}$ dan dilakukan pengulangan sebanyak 2 kali. Hasil maserasi kemudian dipekatkan dengan menggunakan vakum rotary evaporator pada suhu $40^{\circ} \mathrm{C}$. Kemudian di uapkan pelarutnya didalam oven pada suhu $40^{\circ} \mathrm{C}$. Pada penelitian Widyaningtias (2014) dan Budiningrum (2016) proses pembuatan ekstrak yang dilakukan sama dengan proses ekstraksi pada penelitian ini. Perbedaan metode purifikasi pada penelitian ini dengan penelitian Widyaningtias (2014) dan Budiningrum (2016) yaitu pada pelarut yang digunakan pada proses LLE. W dan B menggunakan pelarut $n$-heksan dan akuades (1:2) $\mathrm{v} / \mathrm{v}$ sedangkan pada penelitian ini n-heksan dan akuades (1:1) v/v sehingga pada penelitian Widyaningtias (2014) dan Budiningrum (2016) jumlah kandungan senyawa aktif dalam fraksi etanol-air yang diperoleh dibandingkan dengan penelitian ini berbeda dilihat dari hasil uji aktivitas antibakteri. Pada penelitian Widyaningtias (2014) dan Budiningrum (2016) mampu menghambat pertumbuhan bakteri $\mathrm{P}$. acnes sedangkan fraksi etanol-air yang diperoleh pada penelitian ini tidak mampu menghambat pertumbuhan bakteri $P$. acnes.

\section{Skrining fitokimia dengan KLT}

Pereaksi Anisaldehid-Asam sulfat digunakan untuk mengidentifikasi senyawa golongan terpenoid. Pereaksi Folin-Ciocalteau digunakan untuk mengidentifikasi senyawa golongan Fenol dengan inti katekol, dan Pereaksi $\mathrm{FeCl} 3$ digunakan untuk mengidentifikasi golongan senyawa fenol sederhana. Hasil identifikasi pada keenam fraksi menggunakan ketiga pereaksi terlihat hasil positif 
mengandung senyawa golongan terpenoid, golongan fenol dengan inti katekol dan golongan fenol sederhana (Gambar 1 dan 2).

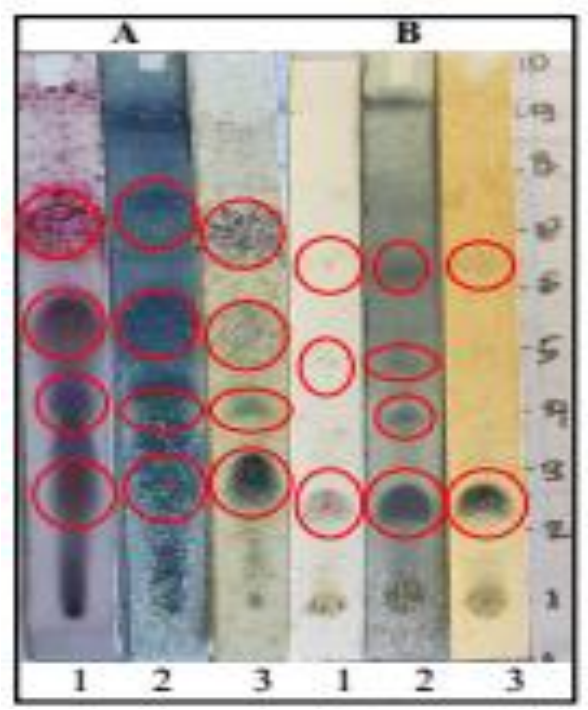

Gambar 1. Hasil Pemisahan A). Fraksi N-heksan dan B).Fraksi Etanol-air (FEAI) dengan Kromatografi Lapis Tipis (KLT) Diamati di Bawah Sinar Tampak setelah disemprot dengan pereaksi 1). Anisaldehid-asam sulfat $\mathrm{P}$; 2). FolinCiocalteau; 3). $\mathrm{FeCl}_{3}$

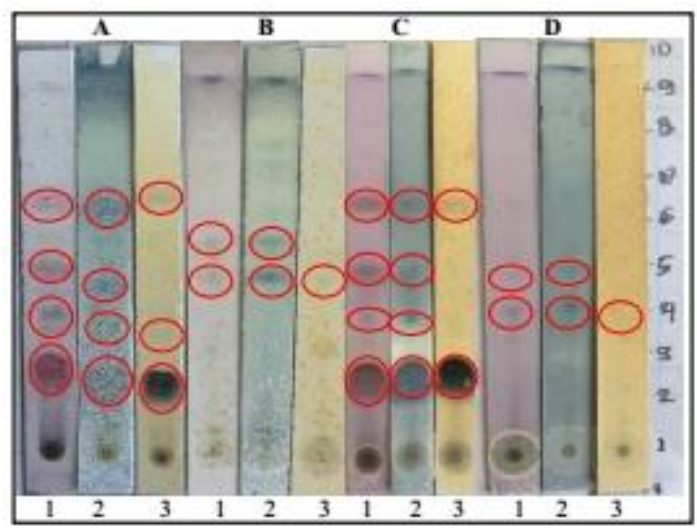

Gambar 2. Hasil Pemisahan A). Fraksi Kloroform, B). Fraksi Etanol-air (FEA II), C).Fraksi Dietileter, D). Fraksi Etanol-air (FEA III) Diamati diBawah Sinar Tampak setelah disemprot dengan pereaksi 1).Anisaldehid-asam sulfat $\mathrm{P} ; 2$ ). FolinCiocalteau; 3). $\mathrm{FeCl}_{3}$
Terlihat adanya kesamaan beberapa spot antar fraksi menunjukkan bahwa proses pemisahan tidak berlangsung maksimal karena kurangnya kontrol KLT selama proses pemisahan. Namun warna spot yang sangat kuat terlihat pada Fraksi Kloroform dan Fraksi Dietil eter menunjukkan bahwa senyawa golongan terpenoid, fenol dengan inti katekol dan fenol sederhana banyak terpartisi di pearut non polar tersebut.

Berdasarkan hasil studi pustaka, beberapa contoh golongan senyawa terpenoid dalam sirih hijau yaitu terpinen, caryophyllene (seskuiterpen) dan fenilpropan (Lisdawati et al., 2008; inayatullah, 2012), golongan senyawa fenol dengan inti katekol pada daun sirih hijau (P. betle Linn.) adalah allylpyrocatechol dan hydroxychavicol, golongan senyawa fenol sederhana yang terdapat pada daun sirih hijau (P. betle Linn) adalah eugenol, chavibetol dan carvacrol. Menurut Wirasuta dan Paramita (2016) senyawa fenol yang aktif sebagai antibakteri terhadap bakteri P. acnes adalah eugenol dan kavikol.

\section{Uji Aktivitas Antibakteri}

Hasil uji aktivitas FH dan FD menghasilkan daya hambat masing masing sebesar $8 \mathrm{~mm}$ dan 9 mm sedangkan FEA I, FEA II, FEA III dan FK tidak memiliki antivitas antibakteri. Ini dapat dilihat dari hasil uji antibakteri yang tidak mampu menghasilkan daya hambat. Hasil uji pada kontrol positif menunjukkan adanya daya hambat terhadap pertumbuhan bakteri $\mathrm{P}$. acnes dengan daya hambat sebesar $42 \mathrm{~mm}$ dimana termasuk dalam kategori susceptible. Perbedaan aktivitas antibakteri disetiap fraksi karena perbedaan jumlah kandungan senyawa aktif yang terdapat dalam setiap sampel. Karena pada pengujian pertama dengan konsentrasi $640 \mathrm{mg} / \mathrm{ml}$ tidak menghasilkan aktivitas maka peneliti mengulang kedua kalinya dengan konsentrasi sebesar $640 \mathrm{mg} / \mathrm{ml}$ namun ke-6 fraksi tidak menghasilkan aktivitas antibakteri. Setelah itu peneliti meningkatkan konsentrasinya menjadi $750 \mathrm{mg} / \mathrm{ml}$ namun ke-6 fraksi tetap tidak menghasilkan aktivitas antibakteri.

Perbedaan hasil uji aktivitas pada penelitian ini dengan penelitian dari Budiningrum (2016) dapat dipengaruhi oleh waktu panen daun sirih hijau, metode pengeringan simplisia sirih hijau. Pada penelitian ini juga tidak dilakukan uji 
aktivitas antibakteri pada ekstrak etanol sebelum dilakukannya purifikasi, sehingga tidak diketahui apakah ekstrak awal terbukti memiliki aktivitas antibakteri yang sama dengan penelitian yang dihasilkan oleh widyaningtias (2014). . Walaupun hasil skrinning KLT fitokimia dari FH dan FD memiliki kesamaan dengan fraksi etanol air pada penelitian Budiningrum (2016) yaitu memiliki senyawa golongan terpenoid, fenol dengan inti katekol dan fenol sederhana, namun diameter daya hambat yang dihasilkan sangat berbeda. Kelemahan penelitian ini adalah tidak adanya pengukuran kadar terhadap senyawa pada Rf tersebut.

\section{SIMPULAN DAN SARAN}

\section{Simpulan}

Berdasarkan hasil penelitian ini dapat disimpulkan bahwa Metode purifikasi ekstrak daun sirih hijau yaitu gabungan metode maserasi dan LLE yang dilakukan belum optimal dilihat hasil uji aktivitas antibakteri dari ke-6 fraksi. Hasil uji aktivitas antibaketri dari ke-6 fraksi belum mampu menghambat pertumbuhan bakteri $P$. acnes dan termasuk dalam kategori resistant.

\section{Saran}

Adapun saran yang dapat diberikan pada penelitian selanjutnya perlu dilengkapi dengan metode KLT Densitometri sebagai kontrol kuantitatif terhadap kadar senyawa aktif untuk menjamin efektivitas dari ekstrak sirih hijau.

\section{UCAPAN TERIMAKASIH}

Penulis mengucapkan terima kasih kepada semua pihak yang telah membantu dalam penelitian ini.

\section{DAFTAR PUSTAKA}

Budiningrum, N. W., 2016, Uji Aktivitas Antibakteri Propionibacterium Acnes Ekstrak Terpurifikasi Daun Sirih Hijau (Piper betle L.) Dari Beberapa Daerah Dengan Zona Iklim Panas (0-700 MDPL) Di BALI Dengan Metode Difusi Disk, Skripsi, Jurusan Farmasi Fakultas Matematika Dan
Ilmu Pengetahuan Alam Universitas Udayana.

Inayatullah, S., 2012, Efek ekstrak daun sirih hijau (Piper betle L.) terhadap Pertumbuhan Bakteri Staphylococcus Aureus. Skripsi. Jakarta. Program Studi Pendidikan Dokter Fakultas Kedokteran dan Ilmu Kesehatan Universitas Islam Negeri Syarif Hidayatullah.

Jesonbabu, J., Spandana N. dan Lakshmi A., 2011, The Potential Activity of Hydroxychavicol against Pathogenic Bacteria, J. Bacteriology Parasitology.Vol.2 (6). Pp: 1-4.

Lisdawati, V., D. Mutiatikum., S. Alegantina dan Y. Astuti, 2008, Karakterisasidaun miana (plectranthus scutellarioides (1.) Bth.) dan buah sirih (piper betle 1.) Secara fisiko kimia dari ramuan lokal antimalaria Daerah Sulawesi Utara. "Puslitbang Biomedis dan Farmasi.

Paramita, N. L. P. V., A. A. G. R. P Yadnya., N. W. Budiningrum., P. S. Yustiantara dan I. M. A. G. Wirasuta, 2016, Detection of antibacterial Compound Of Piper Betle L. Purified extract Againts Propionumbacterium Acnes By Bioautography, Jurusan Farmasi Fakultas Matematika dan Ilmu Pengetahuan Alam Universitas Udayana.

Putri, Z. F., 2010, Uji Aktivitas Antibakteri Ekstrak Etanol Daun Sirih (Piper betle L.) terhadap Propionibacterium acnes dan Staphylococcus aureus multiresisten, Skripsi. Surakarta: Universitas Muhammadiyah Surakarta.

Sylvia L., 2010, Hubungan Antara Jenis Mikroorganisme yang Ditemukan Pada Lesi Akne dengan Bentuk Lesi Akne Di RS Dr.M.Djamil Padang. (Tesis). Padang: Program Pendidikan Dokter Spesialis Fakultas Kedokteran Universitas Andalas.

Widyaningtias, N. M. S. R., 2014, Uji Aktivitas Antibakteri Ekstrak Terpurifikasi Daun Sirih Hijau (Piper betle L.) Terhadap Bakteri Propionibacterium acnes. Skripsi. Jimbaran : Jurusan Farmasi Univeristas Udayana.

Wirasuta, I. M. A. G dan Paramita N. L. P. V., 2016, Anti-Acne Biomarker Identification of Essential Oil Piper betle L. folium, Jurusan 
Farmasi Fakultas Matematika dan Ilmu Pengetahuan Alam Universitas Udayana.

Zainab., F. Gunanti., H. A. Witasari., C. A. Edityaningrum., Mustofa dan $\mathrm{M}$. Murrukmihadi, 2016, Penetapan Parameter Standarisasi Non Spesifik Ekstrak Etanol Daun Belimbing Wuluh (Averrhoa bilimbi l.), Prosiding Rakernas dan Pertemuan Ilmiah Tahunan Ikatan Apoteker Indonesia. 